\title{
ANALISIS HASIL ASETOGENESIS BUNGKIL KOPI PADA SISTEM BIODIGESTER ANAEROB DUA TAHAP
}

\author{
Purwinda Iriani ${ }^{1}$, Puji Ambriani ${ }^{2}$ \\ 1,2 Jurusan Teknik Konversi Energi, Politeknik Negeri Bandung \\ Email : purwinda.iriani@polban.ac.id
}

\begin{abstract}
ABSTRAK
Pada umumnya pembuatan biogas dilakukan melalui proses yang tidak memisahkan proses asetogenesis dan metanogenesis pada reaktor yang berbeda (satu tahap). Pada penelitian ini, dibuat digester asetogenesis dengan kapasitas 30 liter pada kondisi temperatur lingkungan, menggunakan bungkil kopi sebagai bahan baku utama dan kotoran sapi sebagai starter dengan perbandingan 4:1. Waktu fermentasi pada digester asetogenesis selama 34 hari. Kandungan asam asetat dari hasil proses asetogenesis pada hari ke-10 sebesar $0.68 \mathrm{gr} / \mathrm{L}$ dan pada hari ke-23 sebesar $0.76 \mathrm{gr} / \mathrm{L}$. Peningkatan jumlah kandungan asam asetat sebesar $12.27 \%$ atau sebesar $0.08 \mathrm{gr} / \mathrm{L}$ selama 13 hari. Kandungan gas hasil fermentasi yaitu karbondioksida $\left(\mathrm{CO}_{2}\right)$ meningkat dari hari ke10 sebesar $9.55 \%$ sampai hari ke-23 menjadi $49.25 \%$. Peningkatan kandungan asam asetat dan gas $\mathrm{CO}_{2}$ pada digester asetogenesis memunjukan proses asetogenesis dapat memproduksi asam asetat.
\end{abstract}

Kata kunci :biogas, biodigester dua tahap, bungkil kopi, kotoran sapi, asetogenesis.

\section{Abstract}

Biogas is a gas produced by the anaerobic bacteria through the process of fermentation in the biodigester which is generally done on a single-stage process. In this research, a 30 litre-acetogenesis-digester was made, undergone at ambient temperature conditions, using coffee shell as the row material and cow dung as its starter with a ratio of $4: 1$. Fermentation was undergone in 34 days. The concentration of acetic acide on the 10th day was $0.68 \mathrm{gr} / \mathrm{L}$ and on day $23^{\text {rd }}$ was $0.76 \mathrm{gr} / \mathrm{L}$. An increasing mumber of acetic acid concentration was $12.27 \%$ $(0.08 \mathrm{gr} / \mathrm{L})$ in 13 days. The fermentation gas namely Carbon dioxide $\left(\mathrm{CO}_{2}\right)$ increased from $9.55 \%\left(\right.$ day $\left.10^{\text {th }}\right)$ to $49.25 \%$ (day $23^{\text {rd }}$ ). The increasing acetic acid and $\mathrm{CO}_{2}$ gas during acetogenesis process showed that acetogenesis process was successfully produced acetic acid.

Keywords :biogas, two stages fermentation, coffee shell, cow dung, acetogenesis.

\section{PENDAHULUAN}

Diversifikasi bahan baku pembuatan biogas mulai banyak dilakukan, yakni dengan memanfaatkan limbah organik berupa selulosa yang diperoleh dari hasil pertanian dan perkebunan. Salah satu limbah organik yang berpotensi sebagai bahan baku pembuatan biogas adalah bungkil kopi. Lahan Perhutani $\mathrm{KPH}$ Bandung Utara dan KPH Bandung Selatan memiliki 700 hektar lahan yang bisa dimanfaatkan untuk ditanami kopi. Dengan jumlah lahan yang dimanfaatkan untuk perkebunan kopi, maka potensi limbah bungkil yang dapat dihasilkan setiap masa panen adalah hingga 12,600 ton (Puspita, 2012). Pemanfaatan bungkil kopi pada umumnya adalah dijadikan kompos. Pemanfaatan lainnya yang pernah dilakukan Widodo (2011) adalah pembuatan biogas yang dapat menghasilkan gas metan $\left(\mathrm{CH}_{4}\right)$ sebesar $30 \%$.
Proses pembentukan biogas secara garis besar dibedakan menjadi tiga tahapan, yaitu tahap hidrolisis, tahap asetogenesis, dan tahap metanogenesis (Suyitno, 2010). Tahaptahap reaksi pembentukan secara biologis dan kimia pada fermentasi anaerob dapat dilihat pada Gambar 1.

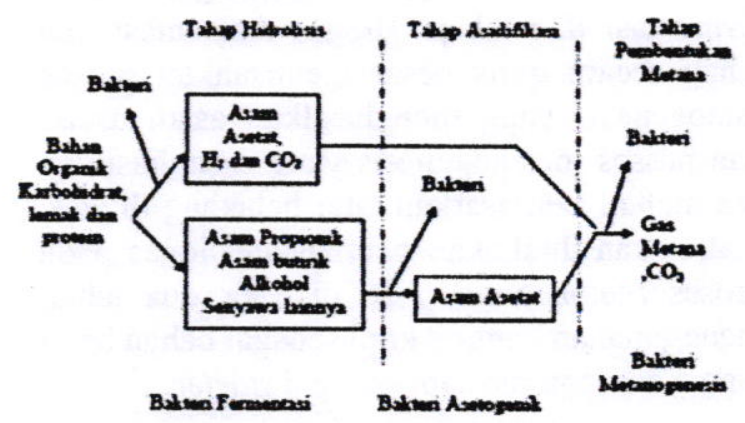

Gambar 1. Tahapan proses pembentukan biogas Sumber: Gerardi, (2003) 
Pada tahap asetogenesis (tahap pembentukan asam asetat), bakteri asetogenik menghasilkan asam untuk mengubah senyawa rantai pendek hasil proses hidrolisis menjadi asam asetat, hidrogen, dan karbondioksida. Bakteri tersebut merupakan bakteri anaerob yang dapat tumbuh dan berkembang dalam keadaan asam, yaitu pada $\mathrm{pH}<5$. Bakteri ini bekerja secara optimum pada temperatur sekitar $30{ }^{\circ} \mathrm{C}$. Bakteri pembentuk asam asetat (Acetobacter aceti) mengubah asam organik dan senyawa netral yang lebih besar dari metanol menjadi asetat dan hidrogen. Pembentukan asam pada kondisi anaerobik tersebut penting untuk pembentukan gas metana oleh mikroorganisme pada proses selanjutnya. Pembentukan biogas tersebut, pada umumnya terjadi di dalam satu tahap dimana pembentukan asam asetat (proses asetogenesis) dan pengubahan asam asetat menjadi gas metan (proses metanogenesis) berada di dalam satu digester. Biogas dengan menggunakan sistem satu tahap memiliki kelemahan karena kedua proses (acetogenesis dan metanogenesis) memiliki kondisi lingkungan tertentu yang dapat mengoptimalkan hasil fermentasi. Proses asetogenesis bereaksi pada nilai $\mathrm{pH} \leq 5$ sedangkan pada proses metanogenesis bereaksi pada nilai $\mathrm{pH}=7$. Hal ini disebabkan pada proses asetogenesis produk yang dihasilkan adalah asam asetat dan senyawa asam lainnya yang mempengaruhi nilai $\mathrm{pH}$ menjadi asam. Nilai $\mathrm{pH}$ yang asam menyebabkan bakteri metanogen tidak bekerja optimal, sehingga mempengaruhi proses metanogenesis pada produk metan yang dihasilkan.

Oleh karena itu, dilakukan pengembangan teknologi biogas untuk meningkatkan produksi biogas yang maksimal, salah satunya dengan teknologi biogas fermentasi dua tahap. Biogas fermentasi dua tahap secara garis besar memisahkan proses asetogenesis yang menghasilkan asam asetat dan proses metanogenesis yang menghasilkan gas metan. Berdasarkan latar belakang di atas, maka akan dilakukan pembuatan biogas pada proses asetogenesis pada digester dua tahap menggunakan bungkil kopi sebagai bahan baku utama dan kotoran sapi sebagai starter.

\section{METODOLOGI}

\begin{abstract}
Alat dan Bahan
Alat yang digunakan dalam pembuatan digester dengan kapasitas 30 liter adalah ragum, gergaji, kikir, tang, bor dengan ukuran mata bor 2 inch, obeng $\min (-)$ dan obeng plus (+), pisau atau cutter, timbangan, amplas, ember pengaduk, corong, gelas ukur $2000 \mathrm{~mL}$, syringe 1 mL. Bahan yang dibutuhkan untuk pembuatan biogas adalah bungkil kopi sebagai bahan baku utama dan kotoran sapi sebagai starter dan bahan yang digunakan untuk membuat digester adalah fiberglass woven roving type 400 , resin polyester, thick block, dempul plastik, talk, pigmen (pewarna), katalis (hardener), pipa PVC ukuran 1 inch dan 2 inch, stop valve $1 / 4$ inch, nipple $1 / 2$ inch $\times 3 / 8$ inch, sock drat luar dan dalam ukuran 2 inch, selang waterpass $1 / 4$ inch dan selang silikon, plastik PE, lem silikon dan lem tangit.
\end{abstract}

\section{Desain Alat Biodigester}

Biodigester yang dirancang menggunakan sistem fermentasi anaerob dengan tipe digester acetogenesis dan metanogenesis yang terpisah (Gambar 2).

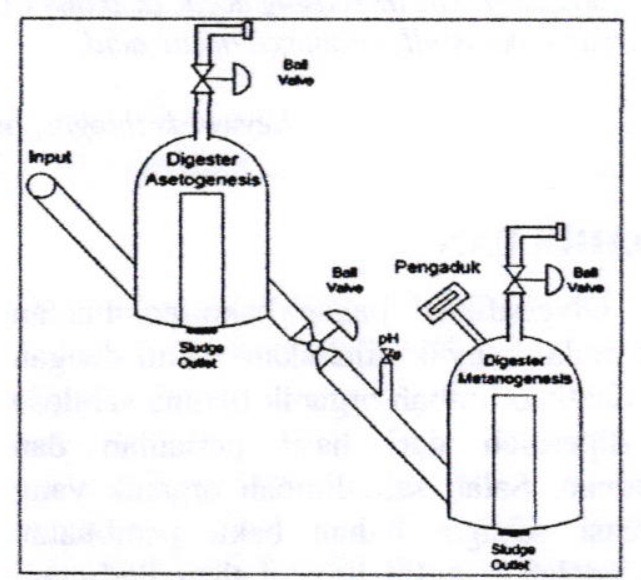

Gambar 2. Desain biodigester 2-tahap

\section{Pengujian Komposisi Kandungan Gas \\ Komposisi gas yang dihasilkan di analisa dengan menggunakan Gas Chromatograf. Analisa ini dilakukan di Laboratorium Metodologi Perancangan Dan Pengendalian Proses Teknik Kimia, Institut Teknologi Bandung. Gas yang terdeteksi oleh alat ini adalah $\mathrm{O}_{2}, \mathrm{H}_{2}, \mathrm{~N}_{2}, \mathrm{CH}_{4}$ dan $\mathrm{CO}_{2}$.}




\section{Pengujian Asam Asetat}

Pada pengujian asam asetat ini dilakukan di Laboratorium Mikrobiologi Teknik Kimia, Institut teknologi Bandung dengan menggunakan pengukuran menggunakan Isocratic HPLC Pump Waters 1515. Pengujian asam asetat menggunakan dua sampel limbah cair hasil fermentasi biogas dengan bahan baku utama bungkil kopi dan kotoran sapi sebagai starter.

Spesifikasi HPLC:

Pompa : Isocratic HPLC Pump Waters 1515

Autosampler : Autosampler Waters 2707

Detektor : Refractive Index Detector Waters 2414

\section{Kondisi Operasi:}

Kolom : Animex HPX87H (BIORAD, CA)

Temperatur Kolom : 60 deg.C

Mobile Phase : $0,005 \mathrm{M} \mathrm{H}_{2} \mathrm{SO}_{4}$

Laju Alir : 0,6 mL/menit

\section{HASIL DAN PEMBAHASAN}

\section{Karakteristik Bahan}

Hasil analisa kimia dari campuran bahan baku dan kotoran sapi (4:1) dapat dilihat pada Tabel 1. Kandungan C-Organik sebesar $52 \%$ dan NOrganik adalah 1,23\%. Nilai C-Organik pada bahan organik pada umumnya sekitar $50-75 \%$ (Mayasari dkk, 2010).

\begin{tabular}{|c|c|c|c|}
\hline \multicolumn{4}{c}{ Tabel 1. Hasil analisa bahan } \\
No. & Parameter & Satuan & Hasil \\
\hline 1 & C-Organik & $\%$ & 52.00 \\
\hline 2 & N-Organik & $\%$ & 1.23 \\
\hline 3 & Kadar air & $\%$ & 93.13 \\
\hline 4 & pH & - & 6.66 \\
\hline 5 & Berat jenis & gr/mL & 0.22 \\
\hline
\end{tabular}

Kebutuhan unsur karbon dapat dipenuhi dari karbohidrat, lemak, dan asam-asam organik (Fry, 1974). Hal tersebut menunjukkan kandungan C-Organik pada bungkil kopi berpengaruh terhadap kadar selulosa yang digunakan pada proses asetogenesis, sehingga kandungan C-Organik tersebut berpotensi untuk dilakukan dalam pembuatan biogas.

Kandungan N-Organik sebesar $1,23 \%$. Nilai NOrganik pada bahan organik pada umumnya sekitar 1,5\% (Mayasari dkk, 2010). Kebutuhan nitrogen dapat dipenuhi dari protein, amoniak dan nitrat (Fry, 1974). Kandungan N-Organik tersebut berguna untuk pertumbuhan bakteri pada proses asetogenesis. Pertumbuhan bakteri tersebut dihasilkan oleh kadar N-Organik yang terdapat pada bahan organik.

Kadar air sebesar 93,13\%. Mikroba penghasil biogas harus berada pada kondisi dengan kadar air yang optimal agar dapat beraktivitas secara normal. Bila air terlalu sedikit, asam asetat terakumulasi sehingga menghambat proses fermentasi, dan juga akan terbentuk lapisan kerak (scum) yang tebal dipermukaan, terutama jika bahan isian berserat. Scum ini akan menghambat gas yang terbentuk ke permukaan. Kadar air yang optimal adalah $90 \%$ dan kadar padatan $8-10 \%$ (Fairus dkk, 2011).

pH pada campuran bungkil kopi sebagai bahan baku utama dan kotoran sapi sebagai starter sebesar 6,66. Bakteri alami pengurai bahan organik dapat berkembang dengan baik pada keadaan yang asam, yaitu $\mathrm{pH}$ antara $4-6$, sehingga pada $\mathrm{pH}$ tersebut akan meningkatkan hasil kandungan asam asetat (Gerardi, 2003). Bila derajat keasaman lebih kecil atau lebih besar dari batas, maka bahan tersebut akan mempunyai sifat toksik terhadap bakteri metanogenik (Fry, 1974).

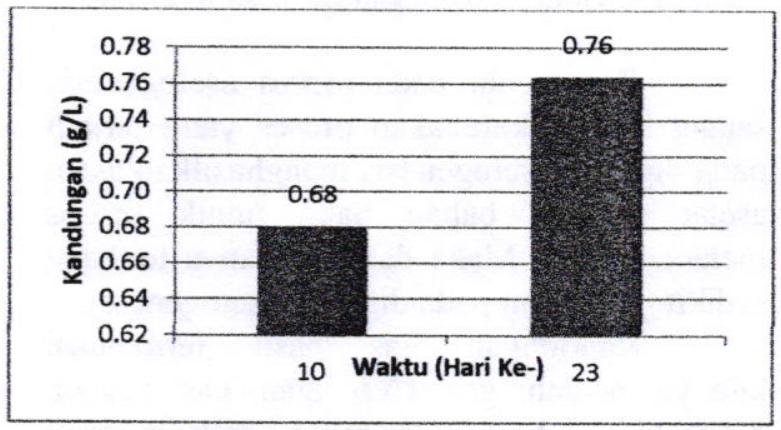

Gambar 3. Grafik kandungan asam asetat

Pada Gambar 3 diperoleh peningkatan kandungan asam asetat pada digester asetogenesis dengan waktu fermentasi selama 23 hari. Pada hasil analisa laboratorium kandungan asam asetat hari ke-10 sebesar 0,68 $\mathrm{g} / \mathrm{L}$ sedangkan pada hasil analisa laboratorium kandungan asam asetat hari ke-23 sebesar 0,76 $\mathrm{g} / \mathrm{L}$. Peningkatan kandungan asam asetat sebesar $12,27 \%$ atau sebesar $0,08 \mathrm{~g} / \mathrm{L}$ dengan waktu fermentasi selama 13 hari.

Peningkatan tersebut membuktikan bahwa bungkil kopi memiliki potensi untuk menghasilkan asam asetat. Konsentrasi asam 
asetat yang dihasilkan $410,4 \mathrm{~g} / \mathrm{L}$ yang berpotensi diperoleh dalam 13 hari waktu fermentasi pada digester asetogenesis.

Selama proses fermentasi pada digester asetogenesis, diujikan pula gas-gas yang dihasilkan. Pada Gambar 4 dapat dilihat proses produksi gas yang bervariasi pada digester asetogenesis. Pada proses asetogenesis, kandungan gas $\mathrm{CH}_{4}$ yang dihasilkan sangat kecil. Kandungan gas $\mathrm{CH}_{4}$ atau gas metan dihasilkan pada hari ke-10 yaitu sebesar $0.05 \%$ dan hari ke-20 sebesar $0.03 \%$. Kandungan gas metan yang dihasilkan sangat kecil, dan pada hari berikutnya tidak terdapat gas metan pada proses asetogenesis.

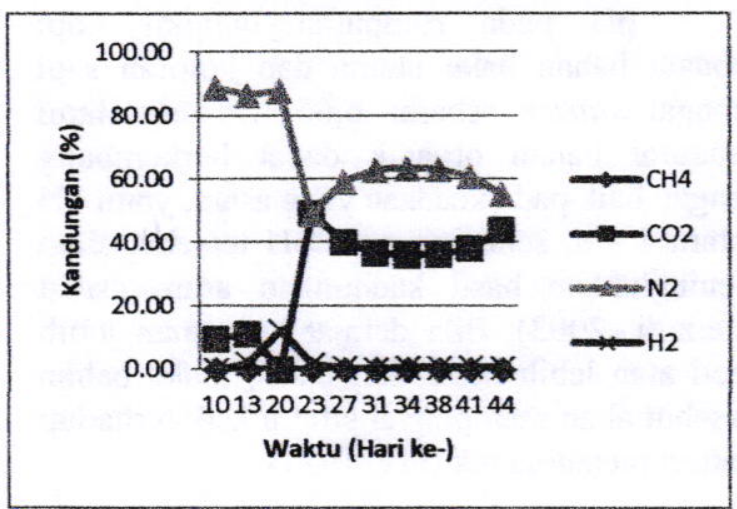

Gambar 4. Grafik kandungan gas hasil fermentasi

Gas metan pada proses asetogenesis sangat kecil dikarenakan proses yang terjadi pada digester asetogenesis menghasilkan asam asetat sebagai bahan baku untuk proses metanogenesis. Maka dari itu, hanya terdapat sedikit gas metan pada digester asetogenesis.

Kandungan gas hasil fermentasi lainnya adalah gas $\mathrm{CO}_{2}$ atau gas karbon dioksida. Kandungan gas karbon dioksida yang dihasilkan dari proses asetogenesis meningkat pada hari ke-10 sampai dengan hari ke-23. Pada hari ke-10, kandungan gas karbondioksida yang dihasilkan sebesar 9,55\% sedangkan pada hari ke-34 kandungan gas karbon dioksida menjadi $35,92 \%$. Pada tinjauan pustaka, komposisi kandungan gas karbon dioksida pada biogas sebesar $25 \%$ - $45 \%$. Dengan demikian, kandungan gas karbon dioksida pada digester asetogenesis masih dalam komposisi yang sesuai untuk memproduksi biogas.

Gas karbon dioksida yang dihasilkan dari proses asetogenesis berpengaruh terhadap kandungan gas asam asetat yang dihasilkan oleh digester asetogenesis, sehingga menunjukkan proses asetogenesis berlangsung. Peningkatan kandungan gas karbondioksida pada digester dapat meningkatkan hasil kandungan asam asetat yang dibutuhkan pada proses metanogenesis untuk memproduksi gas metan.

Kandungan gas lainnya yaitu $\mathrm{N}_{2}$ dan $\mathrm{H}_{2}$ yang dihasilkan oleh digester asetogenesis. Kandungan gas $\mathrm{N}_{2}$ atau gas nitrogen dan kandungan gas $\mathrm{H}_{2}$ atau gas hidrogen dari hasil fermentasi pada digester asetogenesis dipengaruhi oleh udara lingkungan. Kandungan gas nitrogen pada hari ke-10 sampai dengan hari ke-23 mengalami penurunan. Namun, pada hari selanjutnya kandungan gas nitrogen mengalami peningkatan. Pada hari ke-23 kandungan gas nitrogen sebesar 49,12\%. Kandungan gas nitrogen berdasarkan tinjauan pustaka adalah sebesar $0 \%-5 \%$. Jumlah kandungan gas nitrogen yang berlebih dapat mengurangi nilai kalori dan meningkatkan antiknock pada engine. Kandungan gas nitrogen yang berlebih ini dikarenakan kebocoran pada digester yang tidak terlihat. Selain itu, pada saat pengujian sampel gas, syringe yang digunakan masih terdapat udara sehingga meningkatkan kandungan gas nitrogen.

Pada kandungan gas hidrogen, jumlah gas yang dihasilkan paling tinggi pada hari ke-20 yaitu sebesar $12,21 \%$ sedangkan pada data hari lainnya jumlah kandungan gas hidrogen di bawah $2 \%$. Jumlah kandungan gas hidrogen berdasarkan tinjauan pustaka adalah sebesar $0 \%-0,5 \%$. Jumlah kandungan gas hidrogen yang berlebih dapat mengakibatkan korosi pada peralatan dan sistem pemipaan (stress corrosion).

\section{Pengukuran Volume Gas}

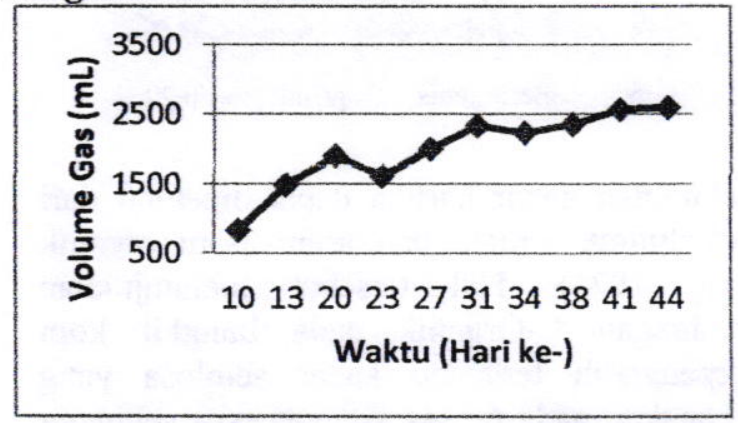

Gambar 5. Grafik volume gas terhadap waktu

Pada Gambar 5 dapat dilihat bahwa jumlah volume gas pada hari ke-10 atau pada saat pengambilan data pertama volume gas 
yang dihasilkan masih sangat kecil yaitu 830 $\mathrm{mL}$. Pada hari ke-31 volume gas meningkat menjadi $2340 \mathrm{~mL}$. Sehingga, dapat diambil nilai rata-rata jumlah volume gas yang dihasilkan dari proses fermentasi digester asetogenesis adalah sebesar $454 \mathrm{~mL}$ perharinya.

\section{KESIMPULAN}

1. Asam asetat yang dihasilkan oleh digester asetogenesis mengalami peningkatan pada hari ke-13 yaitu sebesar $12.27 \%$ atau sebesar $0.08 \mathrm{gr} / \mathrm{L}$.

2. Peningkatan asam asetat didukung oleh gas hasil fermentasi yaitu gas karbondioksida sebesar $49.25 \%$ pada hari ke-23, sehingga menunjukkan proses asetogenesis berlangsung.

\section{DAFTAR PUSTAKA}

Fairus, S., \& dkk. (2011). Pemanfaatan Sampah Organik Secara Terpadu Menjadi Alternatif Energi: Biogas dan Precursor Briket. Bandung: Institut Teknologi Nasional.

Fry, J. L., \& Richard, M. (1973). Methane Digester For Fuel Gas and Fertilizer. New Alchemic Institute's.

Gerardi, M. H. (t.thn.). The Microbiology of Anaerobic Digesters. John Willey and Sons, Inc.

Mayasari, H. D., \& dkk. (2010). Pembuatan Biodigester dengan Uji Coba Kotoran Sapi Sebagai Bahan Baku. Surakarta: Universitas Sebelas Maret.

Puspita, R. (2012). Pengolahan Limbah Kopi Menjadi Energi Alternatif Biogas. Energi Alternatif.

Suyitno. (2010). Teknologi Biogas, Pembuatan, Operasional, dan Pemanfaatan. Yogyakarta: Graha Ilmu.

Widodo, T. (2011). Pemanfaatan Limbah Industri Pertanian Untuk Energi Biogas. Balai Besar Pengembangan Mekanisasi Pertanian Serpong Badan Litbang Pertanian Departemen Pertanian. 